\title{
市街地に位置する既存の大規模樹林地としての京都御苑における 通年の鳥類相
}

\section{高林 裕 1）- 山口史絵 2）・上田瑠香 3） - 福井 亘 *1)}

1）京都府立大学大学院生命環境科学研究科

2）アジア航測株式会社西日本インフラマネジメント技術部

3）大阪市建設局公園緑化部

摘要 : 京都市の市街地に位置する国民公園である京都御苑は, 周 辺の山々や河川などと市街地の緑をつなぐネットワークの拠点 の緑のひとつとして位置づけられている。京都御苑において出現 する鳥類相を通年の調査（2017 年 6 月から 2018 年 5 月）によ って把握することで, 市街地に位置する既存の大規模樹林地の生 物多様性を示すデータを提供することを目的とした。その結果, 9 目 24 科 45 種 7,642 羽の鳥類が確認され, 通年で継続して確認 された種, 春先から夏にかけて個体数が増加する種, 秋から冬に かけて個体数が増加する種, 季節ごとに出現傾向が変化する種 （夏鳥・冬鳥・漂鳥）が存在することが明らかになった。 キーワード : 都市の生物多様性, 鳥類, 京都, 市街地, 大規模樹 林地

\section{1. はじめに}

都市における生物多様性の重要性が指摘されるようになっ て久しく，水と緑のネットワークを都市に形成することが生 物多様性国家戦略 2012-2020 において指針とされている 8)。 加えて, 近年では緑の機能を社会資本整備や土地利用等に活 用するグリーンインフラの考え方が政策にも取り入れられ， 都市における緑の重要性が改めて注目されている 12)。都市の 緑の中でも, 市街地における大規模緑地に着目すると, 新規 造成が困難であることから, 既存の大規模樹林地は存在価值 が高く, 都市の生物多様性の観点からもこれを保全・活用す る意義があると考えられる。京都市の市街地に位置する国民 公園である京都御苑は，「京都市緑の基本計画」において周 辺の山々や河川などの緑と市街地の緑をつなぐネットワーク の拠点のひとつとして位置づけられている大規模樹林地であ る 13)。京都御苑の面積は約 65 ha であり，もともとは賀茂川 の汇濫を繰り返し受けて生成された沖積地であった 9)。明治 10 年（1847 年）から始まった大内保存事業による整備によ って, 現在のような植栽が行なわれてきた ${ }^{17)}$ 。上記のような 過程を経て, 苑内に生育する樹木は約 5 万本, 植物は 500 種 以上であると報告されている 9)。このような特徴を有する京
都御苑であるが, 京都市の市街地における大規模樹林地とし て，市街地の生物多様性の中でどのような役割を担っている のかは明らかにされてはいない。

生物多様性の指標としては生態系ピラミッドの上位種であ る鳥類が多くの研究で用いられており, 鳥類の出現に影響を 与える環境要因について知見の蓄積が進んでいる。例えば, 京都市における鳥類に関する既往研究をみると, 都市近郊に 位置する農地周辺の空間 3)や街路樹 2), 小規模な線状緑地 ${ }^{14)}$, 街区公園 15)などを対象とした研究がみられる。京都市の市街 地における大規模樹林地については, 京都御苑を含む都市林 におけるアオバズク（Ninox scutulata Raffles.）の繁殖可能 性に関する研究 4)や, 梅小路公園のいのちの森（0.6 ha）に おける通年の鳥類相に関する研究 6)などが夕られる。中でも, 橋本ら5)の研究において, 京都市内における京都御苑を含む 複数の孤立林において越冬期と繁殖期に鳥類調査が実施され ており，樹林地面積が大きい孤立林ほど多種の樹林性鳥類が 出現することが確認されている。しかし，京都市において市 街地に位置する既存の大規模樹林地を有する京都御苑を対象 地として, 出現する鳥類の傾向を通年で調査・分析した例は ない。この点を明らかにすることで，京都市の市街地におけ る大規模樹林地としての京都御苑が，市街地の生物多様性の 中でどのような役割を担っているのか，その一端を明らかに することができると考えられる。

以上の背景を踏まえて, 本稿では市街地の大規模樹林地と しての京都御苑における通年での鳥類の出現傾向を把握し, 市街地に位置する既存の大規模樹林地の生物多様性を示すデ ータを提供することを目的とした。

\section{2. 研究方法}

\section{1 鳥類調查}

本調査では京都御苑における鳥類相を網羅的に把握するた めに，できる限り植生や植生の階層構造，土地被覆（水面や 芝生，砂利道，グラウンドなど）の異なる地点を調查地点と

\footnotetext{
* 連絡先著者 (Corresponding author) ： $\bar{\top} 606-8522$ 京都市左京区下鴨半木町 1-5 E-mail : wfukui@kpu.ac.jp
} 


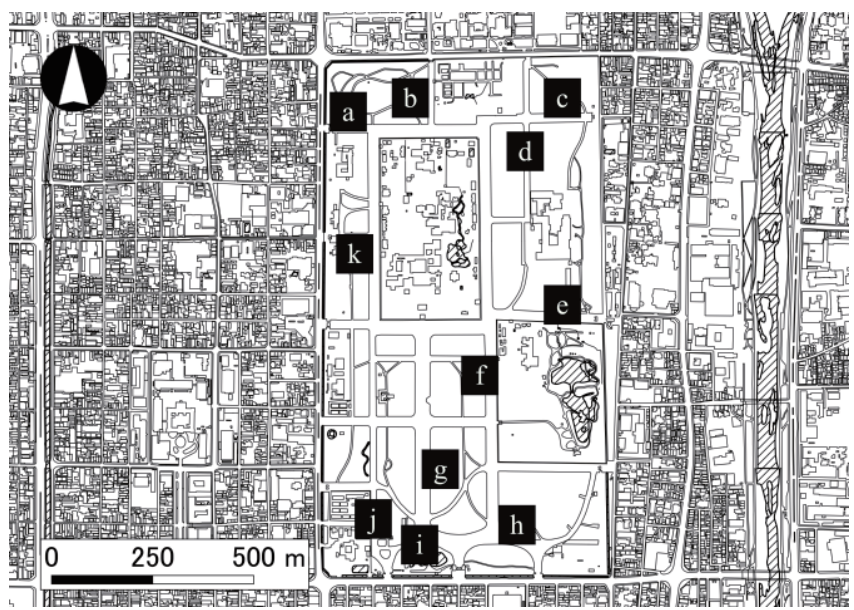

図-1 京都御苑に扮ける調查対象地点

して設定した。調査地点決定のための現地における予備調査 を 2017 年 3 月から 5 月の間に実施し, 地理情報システム

（ESRI 社の Arc Map 10.5）や衛星画像（SPOT 7 が 2016 年 6 月 3 日に撮影, 地上分解能約 $1.5 \mathrm{~m}$ ) を補助的に利用し つつ, 最終的に 11 か所の調查地点を設定した（図-1, 地点 a から地点 k）。本調查の期間は 2017 年 6 月から 2018 年 5 月 までの間として, 各月 2 回ずつ, 計 24 回の鳥類調查を実施 した。調查方法はポイントセンサス法 1)を採用し, 観察半径 は $25 \mathrm{~m}$ とした。調査時間は 10 分間として, 観察圈内に出現 した鳥類の種と個体数を目視で確認・識別し，それぞれ記録 した。調查日の条件は晴れまたは量りの日として, 調査時間 は日の出後すぐから約 3 時間の間に, 全地点の調査を一日で 実施した。調查時間の偏りが生じないように，調查日ごとに 地点を回る順番を反転させて調查を実施した。

\section{2 分析方法}

京都御苑における鳥類相を把握するにあたって, 地点 a か ら地点 $\mathrm{k}$ までの全 11 地点における計 24 回の通年の鳥類調查 の結果を用いて，月ごとおよび繁殖期，越冬期ごとに種別に 集計した。なお, 既往研究 6)を参考にして, 繁殖期は 5 月か ら 7 月, 越冬期は 12 月から 2 月として鳥類の集計を実施し た。出現した鳥類について, 日本鳥類目録改訂第 7 版 ${ }^{18}$ に準 拠する鳥類図鑑 16) や梅小路公園のいのちの森における通年 での鳥類調查の結果を示した既往研究 6), 現地における出現 状況を参考にして, 留鳥と夏鳥, 冬鳥, 漂鳥にそれぞれ区分 し, その出現傾向の特徵を把握した。その後地点 a から地点 $\mathrm{k}$ までの各地点において確認された鳥類について, 通年の調 查による結果を集計し, 種数と多様度指数である Shannon-Wiener $の H^{\prime}$ と Simpson $の D$ を ver.3.6.2 ${ }^{19)}$ のパッケージ vegan 7)を使用して算出した。

\section{3. 結果}

月ごとの各種の出現状況を表-1 に示した。計 24 回の鳥類 調查の結果, 全 11 地点における通年で確認された鳥類は 9 目 24 科 45 種 7,642 羽であった。また, 繁殖期は 8 目 21 科 30 種 1,733 羽, 越冬期は 8 目 20 科 31 種 2,699 羽の鳥類が それぞれ確認された。

通年で継続して確認されたのは，ドバトとアオサギ，コゲ ラ, 八シボソガラス, 八シブトガラス, シジュウカラ, ヒヨ ドリ, メジロ, スズメであった。留鳥のうち, 春先から夏に かけて個体数の増加傾向が確認された種はアオサギと八シブ トガラス, スズメ, カワラヒワであった。留鳥のうち, 秋か ら冬にかけて個体数の増加傾向が確認された種は, キジバ卜 とモズ, シジュウカラ, ヒヨドリ, メジロ, イカルであった。 夏鳥として確認された種は，アオバズク（5 月）とサンコウ チョウ（5，6 月），エゾムシクイ $(4 ， 5$ 月），センダイム シクイ（5月），キビタキ（4月から 6 月）であった。冬鳥 として確認された種は，マガモ（10月から 3 月，5月）と） スリ（4月），シロ八ラ（11月から 4 月），ツグミ（12月 から 4 月），ジョウビタキ（11月から 1 月），アトリ（12 月から 4 月）であった。漂鳥として確認された種はアオバト (3 月から 5 月) とヒガラ (3月)，トラッグミ（3月），ビ ンズイ（1月から 3 月）であった。

各地点において確認された鳥類の出現種数と多梯度指数の 結果を表-2 にまとめた。地点ごとの種数と多様度指数の結果 から, 通年での平均值はそれぞれ, 種数が 27.91 種, $H^{\prime}$ が 3.66, $D$ が 0.87 であり, 繁殖期での平均值はそれぞれ, 種 数が 16.27 種, $H^{\prime}$ が $3.19, D$ が 0.84 であり, 越冬期での平 均值はそれぞれ，種数が 18.55 種， $H^{\prime}$ が $2.92, D$ が 0.75 であった。

\section{4. 考察}

通年の鳥類調查の結果，京都御苑において出現する鳥類の 特徴として, 通年で継続して確認された種や春先から夏にか けて個体数が増加する種, 秋から冬にかけて個体数が増加す る種，季節ごとに出現傾向が変化する種 $($ 夏鳥・冬鳥・漂鳥) が存在することが明らかになった。

通年で継続して出現したドバトとアオサギ，コゲラ，ハシ ボソガラス, ハシブトガラス, シジュウカラ, ヒヨドリ, メ ジロ，スズメは，京都御苑を生息場所として利用しているこ とが考えられた。市街地においては都市忌避種と分類される こともあるコゲラ $10,11,15)$ が通年で常時確認されたのは, 周辺 を山々で囲まれた京都の特徽が反映された結果であると考え られた。また, アオサギが樹上にコロニーを形成している様 子も確認された。春先から夏にかけて個体数が増加したアオ サギとハシブトガラス, スズメ, カワラヒワに関しては, 鳥 類の繁殖期と重なることもあり, 京渡御苑もしくは鴨川など の近郊の緑地において繁殖している可能性が考えられた。八 シブトガラスや夏鳥であるアオバズクに関しては, 苑内で営 巣していることが調査中に確認できた。秋から冬にかけて個 
表-1 鳥類調査結果（地点 $\mathrm{a}$ から地点 $\mathrm{k}$ の合計值, 羽）

\begin{tabular}{|c|c|c|c|c|c|c|c|c|c|c|c|c|c|}
\hline 種名 & $\begin{array}{l}\text { 分 } \\
\end{array}$ & 6 月 & 7月 & 8月 & 9 月 & 10 月 & 11 月 & 12 月 & 1 月 & 2 月 & 3 月 & 4 月 & 5 月 \\
\hline カルガモ Anas zonorhyncha Swinhoe. & 留 & 1 & 1 & 0 & 1 & 2 & 0 & 6 & 0 & 0 & 0 & 0 & 0 \\
\hline キジバト Streptopelia orientalis Latham. & 留 & 7 & 8 & 8 & 6 & 1 & 4 & 7 & 40 & 23 & 17 & 17 & 9 \\
\hline アオバト Treron sieboldii Temminck. & 漂 & 0 & 0 & 0 & 0 & 0 & 0 & 0 & 0 & 0 & 7 & 2 & 2 \\
\hline カワウ Phalacrocorax carbo Linnaeus. & 留 & 1 & 1 & 0 & 0 & 3 & 0 & 0 & 0 & 1 & 1 & 0 & 0 \\
\hline ゴイサギ Nycticorax nycticorax Linnaeus. & 留 & 0 & 0 & 1 & 0 & 0 & 0 & 0 & 0 & 0 & 0 & 0 & 0 \\
\hline トビ Milvus migrans Boddaert. & 留 & 6 & 9 & 3 & 2 & 8 & 2 & 5 & 6 & 5 & 4 & 2 & 3 \\
\hline オオタカ Accipiter gentilis Linnaeus. & 留 & 1 & 0 & 0 & 0 & 0 & 0 & 0 & 1 & 0 & 2 & 1 & 1 \\
\hline ノスリ Buteo buteo Linnaeus. & 冬 & 0 & 0 & 0 & 0 & 0 & 0 & 0 & 0 & 0 & 0 & 1 & 0 \\
\hline アオバズク Ninox scutulata Raffles. & 夏 & 0 & 0 & 0 & 0 & 0 & 0 & 0 & 0 & 0 & 0 & 0 & 1 \\
\hline カワセミ Alcedo atthis Linnaeus. & 留 & 0 & 0 & 0 & 0 & 0 & 0 & 1 & 2 & 0 & 0 & 3 & 0 \\
\hline コゲラ Dendrocopos kizuki Temminck. & 留 & 8 & 16 & 11 & 7 & 17 & 9 & 14 & 17 & 13 & 20 & 11 & 12 \\
\hline サンコウチョウ Terpsiphone atrocaudata Eyton. & 夏 & 1 & 0 & 0 & 0 & 0 & 0 & 0 & 0 & 0 & 0 & 0 & 2 \\
\hline ヒガラ Periparus ater Linnaeus. & 漂 & 0 & 0 & 0 & 0 & 0 & 0 & 0 & 0 & 0 & 2 & 0 & 0 \\
\hline シジュウカラ Parus minor Temminck \& Schlegel. & 留 & 32 & 21 & 15 & 44 & 39 & 28 & 20 & 45 & 50 & 51 & 53 & 85 \\
\hline ツバメ Hirundo rustica Linnaeus. & 夏 & 19 & 34 & 4 & 3 & 0 & 0 & 0 & 0 & 0 & 0 & 3 & 4 \\
\hline ヒヨドリ Hypsipetes amaurotis Temminck. & 留 & 5 & 4 & 5 & 16 & 100 & 136 & 118 & 85 & 42 & 41 & 16 & 29 \\
\hline ウグイス Cettia diphone Kittlitz. & 留 & 0 & 0 & 0 & 0 & 0 & 5 & 4 & 2 & 1 & 5 & 6 & 3 \\
\hline エナガ Aegithalos caudatus Linnaeus. & 留 & 19 & 0 & 18 & 0 & 12 & 30 & 9 & 12 & 13 & 38 & 13 & 33 \\
\hline $\begin{array}{l}\text { センダイムシクイ } \\
\text { Phylloscopus coronatus Temminck \& Schlegel. }\end{array}$ & 夏 & 0 & 0 & 0 & 0 & 0 & 0 & 0 & 0 & 0 & 0 & 0 & 5 \\
\hline エゾムシクイ Phylloscopus borealoides Portenko. & 夏 & 0 & 0 & 0 & 0 & 0 & 0 & 0 & 0 & 0 & 0 & 1 & 2 \\
\hline メジロ Zosterops japonicus Temminck \& Schlegel. & 留 & 30 & 28 & 22 & 41 & 62 & 39 & 44 & 34 & 16 & 21 & 25 & 31 \\
\hline ムクドリ Spodiopsar cineraceus Temminck. & 留 & 15 & 113 & 0 & 0 & 40 & 105 & 5 & 9 & 30 & 18 & 42 & 74 \\
\hline トラツグミ Zoothera dauma Latham. & 漂 & 0 & 0 & 0 & 0 & 0 & 0 & 0 & 0 & 0 & 1 & 0 & 0 \\
\hline シロハラ Turdus pallidus Gmelin. & 冬 & 0 & 0 & 0 & 0 & 0 & 5 & 7 & 27 & 29 & 21 & 2 & 0 \\
\hline カワラヒワ Chloris sinica Linnaeus. & 留 & 24 & 33 & 10 & 0 & 9 & 5 & 4 & 18 & 25 & 37 & 66 & 32 \\
\hline シメ Coccothraustes Coccothraustes Linnaeus. & 漂 & 0 & 0 & 0 & 0 & 100 & 2 & 0 & 0 & 0 & 0 & 0 & 0 \\
\hline イカル Eophona personata Temminck \& Schlegel. & 留 & 1 & 0 & 0 & 37 & 36 & 83 & 197 & 896 & 218 & 128 & 39 & 17 \\
\hline アオジ Emberiza spodocephala Pallas. & 漂 & 0 & 0 & 0 & 7 & 1 & 6 & 3 & 0 & 1 & 1 & 8 & 0 \\
\hline 総個体数 & & 453 & 474 & 325 & 308 & 652 & 633 & 632 & 1,429 & 638 & 709 & 583 & 806 \\
\hline 種数 & & 23 & 18 & 15 & 18 & 24 & 25 & 28 & 28 & 27 & 31 & 29 & 28 \\
\hline
\end{tabular}

※区分 留: 留鳥, 夏: 夏鳥, 冬: 冬鳥, 漂: 漂鳥

体数が増加していたキジバトとモズ，シジュウカラ，ヒヨド リ，メジロ，イカルは，既往研究 10)においても指摘されてい るように, 市街地に餌を求めて出現しているために増加して いるものと考えられた。特に, 越冬期においては樹林性鳥類 であるイカルが 1,311 羽確認された。イカルは地点 $\mathrm{d}$ におい て 1 月の調査中に著しく多くの個体数が出現し, 歩道から離 れた比較的開けた地上部において集団で採食している様子が 確認され, 地点 $\mathrm{d}$ において通年および越冬期の $H^{\prime}$ と $D$ が他 の地点よりも低い值を示したのはこのためであると解釈でき た。また, シジュウカラやヒヨドリ，メジロは通年で継続し て確認されたが, 秋から冬にかけて個体数が増加しているた
め, 周辺の山林等から飛来してきた個体も含まれていると考 えられた。京都御苑は市街地に位置しながらもそれだけ多く の個体が生息できる緑地であることが推察された。夏鳥（ア オバズクとサンコウチョウ, エゾムシクイ, センダイムシク イ, キビタキ）や冬鳥（マガモとノスリ，シロハラ，ツグミ， ジョウビタキ, アトリ）, 漂鳥（アオバトとヒガラ, トラツ グミ，ビンズイ）に関しては，それぞれ京都御苑を移動の中 継地やその季節の間の生息地として利用していることが考え られ，京都御苑が緑のネットワークの拠点として機能してい る可能性が示唆された。

各地点において確認された鳥類の出現種数と多様度指数の 
表-2 地点ごとの鳥類種数（種）と多様度指数

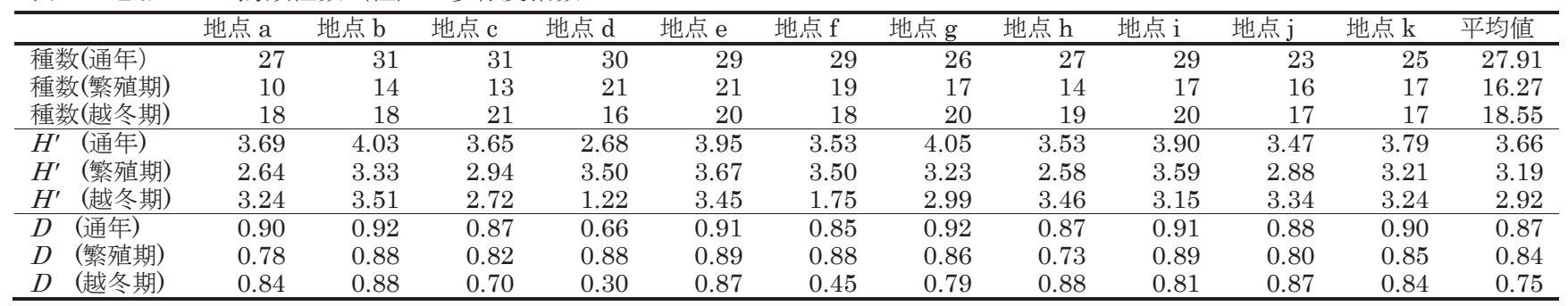

結果から，地点ごとの出現傾向に著しい違いはみられなかっ た。ただし，繁殖期における地点 $\mathrm{a}$ や地点 $\mathrm{b}$, 地点 $\mathrm{c}$ ，地点 $\mathrm{h}$ における出現種数は他の地点よりもやや低い傾向を示した。

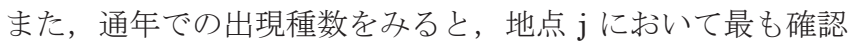
された種数が少ない結果が得られた。今回，鳥類相を網羅的 に把握するために，できる限り植生や植生の階層構造，土地 被覆の異なる地点を調査地点として設定したが，地点ごとの 環境について詳細な調査を実施していないため, 京都御苑内 の環境の違いが出現する種に及ぼす影響については今後の検 討課題と言える。

本稿では一年間の鳥類データを用いて分析したが，年によ る出現傾向の違いや経年変化に伴う鳥類相の変化も予想され る。今後はモニタリング調査の継続に加えて他都市の大規模 樹林地での結果と比較することで, 各都市の特徵を踏まえた 生物多様性に関する知見が得られると考えられよう。

謝辞：本技術報告の一部は株式会社パスコと京都府立大学と の共同研究（CM20171023）「森林地域等における三次元空 間情報解析技術に関寸る高度化研究」と科研費基盤 $\mathrm{B}$

（18H02226）「都市と周辺の緑地が維持する環境緩和機能 及び生物多様性維持機能の総合的評価」の助成を受けました。 また，当時の環境省近畿地方環境事務所長の田村省二氏には 大変お世話になりました。関係各位に厚く感謝申し上げます。

\section{引用文献}

1) Bibby, C. J. ,Burgess, N. D. ,Hill, D. A. , and Mastoe S. H. (2000) Bird census techniques second edition. Academic Press, 91-112.

2) 福井 亘・西野 冴 (2014) 京都市中心部の街路樹と鳥類出 現との関係について. 日本緑化工学会誌, 40 (1) : 223-226.

3）濱田 梓・福井 亘・水島 真 ・瀬古祥子 (2016) 広域的視 点による都市および近郊農業地の土地利用状況と鳥類との 関係。日本緑化工学会誌, 42 (1) : 62-67.

4）橋本啓史・澤邦之・森本幸裕・西尾伸也（2004）京都市街地 都市林におけるアオバズクの生育環境適合度モデル．ラン ドスケープ研究, 67 (5) : 483-486.

5）橋本啓史・村上健太郎・森本幸裕（2005）京都市内孤立林に おける樹林性鳥類の相対種数-面積関係と種組成の入れ子パ ターン. 景観生態学, 10 (1) : 25 - 35 .
6）橋本啓史・中村進・長谷川美奈子・夏原由博・森本幸裕 $(2005)$

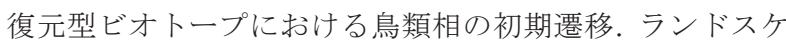
ープ研究, 68 (5) : 559-562.

7) Jari Oksanen et al. (更新：2019 年 9 月 1 日) “vegan: Community Ecology Package. $\mathrm{R}$ package version 2.5-6. ” . https://CRAN.R-project.org/package=vegan（参 照: 2020 年 4 月 8 日).

8）環境省（2012）生物多様性国家戦略 2012-2020. 環境省, $252 \mathrm{pp}$.

9）環境省。（更新： 2020 年 4 月 8 日）“京都御苑”。環境省小 ームページ.

https://www.env.go.jp/garden/kyotogyoen/1_intro/outline. $h t m l$ (参照: 2020 年 4 月 8 日) .

10）加藤和弘 - 吉田亮一郎 - 高橋俊守 - 笠原里恵 - 一八瀬友博 （2015）都市および近郊の小規模樹林地で記録された鳥類の 種組成に影響する要因.ランドスケープ研究，78(5), 671-676.

11）加藤和弘・若山睦月（2017）千葉市西部の住宅地における鳥 類相を規定する要因. ランドスケープ研究，80 (5), 723-726.

12）国土交通省（2015）国土形成計画（全国計画）国土交通省, 173pp.

13）京都市（2010）京都市緑の基本計画. 京都市, 88pp.

14）宮本脩詩・福井 亘（2014）琵琶湖疎水およびその周辺環境 条件と鳥類群集との関係。日本緑化工学会誌，40（1）: 108-113.

15）宮本脩詩・福井 亘・高林 裕（2019）街区公園に出現する 繁殖期の鳥類相に小規模線状緑地が与える移動路としての 寡少な影響. ランドスケープ研究（オンライン論文集）， Vol.12:1-9.

16）水谷高英・叶内拓哉（2017）フィールド図鑑 日本の野鳥. 文一総合出版, 431pp.

17）森 忠文（1978）明治初期における京都御苑の造成につい て. 造園雑誌, 41 (3) : 14-23.

18）日本鳥学会 (2012) 「日本鳥類目録」改訂第 7 版. 日本鳥学 会, 438pp.

19） $\mathrm{R}$ Core Team. (更新：2020 年 3 月 12 日) “ $\mathrm{R}$ : A language and environment for statistical computing. R Foundation for Statistical Computing, Vienna, Austria." . https://www.R-project.org/ (参照: 2020 年 4 月 8 日).

(2020 年 7 月 9 日受理) 